\title{
Effect of lipopolysaccharide (LPS) and peptidoglycan (PGN) on human mast cell numbers, cytokine production, and protease composition
}

\author{
Arnold S Kirshenbaum*1, Emily Swindle ${ }^{1}$, Marianna Kulka ${ }^{2}$, Yalin $\mathrm{Wu}^{1}$ and \\ Dean D Metcalfe ${ }^{1}$
}

\author{
Address: ${ }^{1}$ Laboratory of Allergic Diseases, National Institute of Allergy and Infectious Diseases, National Institutes of Health, Bethesda, MD 20892, \\ USA and 2Institute for Nutrisciences and Health, NRC Canada, 550 University Avenue, Charlottetown, PE, C1A 4P3, Canada \\ Email: Arnold S Kirshenbaum* - akirshenba@niaid.nih.gov; Emily Swindle - emilyswindle@hotmail.com; \\ Marianna Kulka - marianna.kulka@nrc-cnrc.gc.ca; YalinWu - ywu@niaid.nih.gov; Dean D Metcalfe - ddmetcalfe@niaid.nih.gov \\ * Corresponding author
}

Published: 7 August 2008

BMC Immunology 2008, 9:45 doi:10.1 186/147/-2172-9-45

This article is available from: http://www.biomedcentral.com/I47/-2/72/9/45

(C) 2008 Kirshenbaum et al; licensee BioMed Central Ltd.

This is an Open Access article distributed under the terms of the Creative Commons Attribution License (http://creativecommons.org/licenses/by/2.0), which permits unrestricted use, distribution, and reproduction in any medium, provided the original work is properly cited.

\begin{abstract}
Background: Human mast cell (HuMC) maturation occurs in tissues interfacing with the external environment, exposing both mast cell progenitors and mature mast cells, to bacteria and their products. It is unknown, however, whether long- or short-term exposure to bacteria-derived tolllike receptor (TLR) ligands, such as lipopolysaccharide (LPS) or peptidoglycan (PGN), influences HuMC biology.

Results: Over 6 wks of culture, LPS had minimal effect on HuMC numbers but increased CDI I7, tryptase and chymase expression. PGN inhibited HuMC development. For mature mast cells, LPS in the presence of rhSCF $(10 \mathrm{ng} / \mathrm{ml})$ increased CDII7, tryptase, chymase and carboxypeptidase expression, primarily in CDII 7 low HuMC. LPS decreased Fc\&RI expression and $\beta$-hexosaminidase release; but had no effect on $\mathrm{LTC}_{4}$ and $\mathrm{PGD}_{2}$ production. PGN reduced HuMC numbers; and CDII7 and tryptase expression. IL-I $\beta$ and IL-6 (in addition to IL-8 and IL-I2) were detected in short-term culture supernatants of LPS treated cells, and reproduced the increases in CDII7, tryptase, chymase, and carboxypeptidase expression observed in the presence of LPS. Comparative studies with mouse bone marrow-derived mast cells from wild type, but not TLR4 knockout mice, showed increases in mRNA of mouse mast cell chymases MMCP-I, MMCP-2 and MMCP-4.

Conclusion: PGN inhibits HuMC growth, while LPS exerts its primary effects on mature HuMC by altering cytokine production and protease composition, particularly at low concentrations of SCF. These data demonstrate the ability of bacterial products to alter HuMC mediator production, granular content, and number which may be particularly relevant at mucosal sites where HuMC are exposed to these products.
\end{abstract}

\section{Background}

Human mast cells (HuMC) originate from bone marrowderived $\mathrm{CD}_{34}{ }^{+}$pluripotent progenitor cells [1] and migrate as immature cells from the bone marrow to tissue sites including the lung and gastrointestinal tract. There they mature and participate in both innate and acquired 
immune responses with production of cytokines and other inflammatory mediators [2]. Mast cell growth and development thus may occur in a tissue that interfaces with the external environment, potentially exposing HuMC during their development to bacterial products which could have an impact on their subsequent behavior. Consistent with this idea is the observation that HuMC have been shown to express Toll-like receptors (TLR) 1-7, and 9 both in vitro and in vivo (lung) [3]; and exposure to such bacterial products as endotoxin (lipopolysaccharide; LPS) or peptidoglycan (PGN) leads to expression and release of TNF- $\alpha$, GM-CSF, IL-1, IL-5, IL10, IL-13 and IL-15 [4-6]. However, and in a related question, it is currently not known whether bacteria-derived products alter the growth and development of HuMC.

We therefore asked whether long or short-term exposure to LPS and PGN could alter specific HuMC characteristics including growth; surface FceRI and CD117 expression; and $\beta$-hexosaminidase, $\mathrm{LTC}_{4}$ and $\mathrm{PGD}_{2}$ release; protease expression and composition, and cytokine release. As will be shown, LPS augmented protease expression and altered protease composition in developing and mature HuMC, while reducing Fc\&RI expression and IgE-mediated degranulation. This effect in short-term cultures was mediated through HuMC release of IL-1 $\beta$ and IL-6. PGN inhibited HuMC growth at all concentrations studied.

\section{Results}

Effect of LPS and PGN on progenitor HuMC in 6 wk (longterm) cultures

To determine the effect of LPS or PGN over 6 wks on HuMC growth and development, $10-1000 \mathrm{ng} / \mathrm{ml}$ LPS or $10-1000 \mu \mathrm{g} / \mathrm{ml} \mathrm{PGN}$ was added to CD34+ cultures containing $100 \mathrm{ng} / \mathrm{ml}$ rhSCF. Kimura's staining of metachromatic positive HuMC correlated with tryptase staining of HuMC granules on cytopreparations, did not differ by greater than 5\%, and was used for counting small numbers of HuMCs available to study, with minimal cell loss. As shown in Figure 1A, incubation of CD34+ cells with SCF alone resulted in increased total cell numbers by 3 wks which then gradually declined by 6 wks, while HuMC numbers rose steadily from 2-4 wks and were sustained up to 6 wks, by which time all cells in culture were HuMC. The addition of LPS to CD34+ cells over 6 wks of culture had no effect on total cell or HuMC numbers (Fig. 1B). In contrast, PGN initially increased total cell numbers by 1 3 wks, but this increase was short lived, and total numbers rapidly declined after 2-3 wks (Fig. 1C). HuMC growth was totally suppressed by PGN at $1000 \mu \mathrm{g} / \mathrm{ml}$ while PGN at $100 \mu \mathrm{g} / \mathrm{ml}$ suppressed HuMC growth by 3 wks. HuMC were seen in culture in the presence of $10 \mu \mathrm{g} / \mathrm{ml}$ PGN, but numbers were less than half of numbers seen with rhSCF alone (Fig. 1C; compare with 1A). Inhibition of HuMC growth was also seen with another TLR2 agonist, lipotei- choic acid (LTA). As seen in Figure 1D, LTA at 1.0-10 $\mu \mathrm{g} /$ $\mathrm{ml}$ decreased total cell numbers starting at 2-3 wks. The addition of LTA at $1.0-10 \mu \mathrm{g} / \mathrm{ml}$ suppressed HuMC growth beginning at 3-4 wks and for the duration of the cultures (Fig. 1D; compare with 1A). Thus, the addition of LPS over 6 wks did not alter HuMC numbers while PGN and LTA inhibited HuMC outgrowth.

\section{Effect of LPS and PGN on 8 wk old HuMC CDI I 7 and Fc $\&$ RI expression in $\mathbf{7 2} \mathbf{~ h r}$ (short-term) cultures}

We next reasoned that exposure to LPS or PGN would occur to more mature mast cells in some situations and promote HuMC differentiation. We thus cultured mature $8 \mathrm{wk}$ old HuMC in either $100 \mathrm{ng} / \mathrm{ml}$ or $10 \mathrm{ng} / \mathrm{ml} \mathrm{rhSCF}$ in the presence or absence of $100 \mathrm{ng} / \mathrm{ml} \mathrm{LPS} \mathrm{or} 10 \mu \mathrm{g} / \mathrm{ml}$ PGN (selected on the basis of long term culture results) for 72 hrs. Cells were then counted, harvested and examined by flow cytometry for FceRI and CD117 expression. LPS $100 \mathrm{ng} / \mathrm{ml}$ or $10 \mathrm{ng} / \mathrm{ml}$ PGN had no effect on HuMC numbers when cultured in combination with rhSCF 100 $\mathrm{ng} / \mathrm{ml}$ for $72 \mathrm{hr}$. When rhSCF was reduced to $10 \mathrm{ng} / \mathrm{ml}$ (Fig. 2A), HuMC numbers decreased consistent with less rhSCF in the cultures. Viability of the remaining HuMC after 72 hrs ranged from $90-95 \%$. The added presence of LPS increased HuMC numbers after 72 hrs as compared with rhSCF alone $(\mathrm{n}=3, \mathrm{p}<0.01)$, while PGN again resulted in fewer HuMC in culture $(\mathrm{n}=3, \mathrm{p}<0.01)$. The addition of either $10 \mu \mathrm{g} / \mathrm{ml} \mathrm{PGN} \mathrm{or} 10 \mu \mathrm{g} / \mathrm{ml}$ LTA caused an increase of approximately $27 \%$ and $55 \%$, respectively, of apoptotic cells compared to cultures in $10 \mathrm{ng} / \mathrm{ml} \mathrm{rhSCF}$ alone, in contrast to $100 \mathrm{ng} / \mathrm{ml}$ LPS which reduced apoptosis by approximately $50 \%$. To eliminate cell debris or any monocytes from being analyzed, CD117 $/ \mathrm{Fc} \mathrm{RI}^{+}$ HuMC were gated, followed by examination for other surface markers or intracellular proteases. As shown in Figure $2 \mathrm{~B}$, in the presence of $100 \mathrm{ng} / \mathrm{ml} \mathrm{rhSCF}$, a homogeneous population of $\mathrm{CD} 117^{+} / \mathrm{Fc}_{\mathrm{CRI}}{ }^{+} \mathrm{HuMC}$ was seen (approximately $70 \%$ ). In the added presence of $100 \mathrm{ng} / \mathrm{ml}$ LPS, CD $117^{+} / \mathrm{Fc} \mathrm{RI}^{+}$cells decreased by approximately $7 \%$ for HuMC, with a concurrent decrease in FceRI expression (right lower quadrant). Reducing the concentration of rhSCF to $10 \mathrm{ng} / \mathrm{ml}$ for $72 \mathrm{hrs}$ (Fig. 2C) gave rise to two distinct HuMC CD117+ subpopulations: CD117 low (open arrows) and CD117high (solid arrows), with a log-fold increase in MFI for CD117high cells as compared with cultures using $100 \mathrm{ng} / \mathrm{ml}$ rhSCF alone (Fig. 2C inserts). The addition of $100 \mathrm{ng} / \mathrm{ml}$ LPS over 72 hrs to CD117low and CD117high HuMC maintained in $10 \mathrm{ng} / \mathrm{ml}$ rhSCF decreased FceRI expression on CD117 $/ 7^{+} \mathrm{Fc}_{\mathrm{RI}}{ }^{+}$cells (right lower quadrant) by approximately $9 \%$. Histochemical examination of CD117 high and CD117low cells confirmed that both populations shared characteristics, such as numerous surface projections, large and irregular nuclei, and abundant cytoplasmic granules, consistent with cultured HuMC, as described [7]. Thus, FceRI+ expression on 

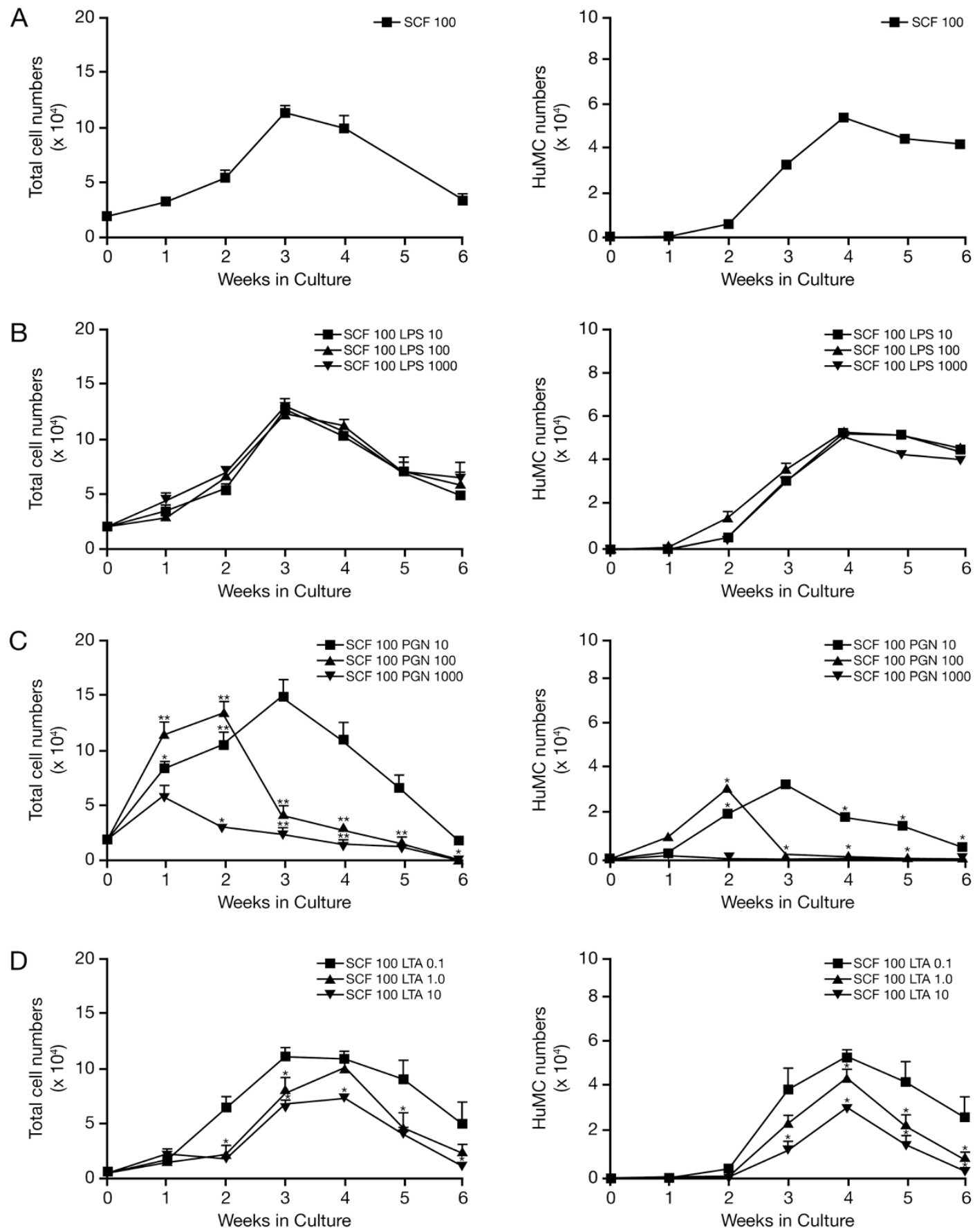

Figure 1

\section{Figure I}

Cultures of CD34+ derived HuMC over 6 wks in the presence of rhSCF alone, or with LPS, PGN or LTA. (A-D): Total cell numbers - left; HuMC numbers- right. A) $100 \mathrm{ng} / \mathrm{ml} \mathrm{rhSCF}$; B) $100 \mathrm{ng} / \mathrm{ml} \mathrm{rhSCF}$ and I0-1000 ng/ml LPS; C) I00 ng/ $\mathrm{ml} \mathrm{rhSCF}$ and $10-1000 \mu \mathrm{g} / \mathrm{ml} \mathrm{PGN}$. Results are shown as the mean \pm SEM of 3 separate experiments performed in duplicate; D) $100 \mathrm{ng} / \mathrm{ml} \mathrm{rhSCF}$ and $0.1-10 \mu \mathrm{g} / \mathrm{ml}$ LTA. Results are shown as the mean \pm SEM of 2 separate experiments performed in triplicate. 
A

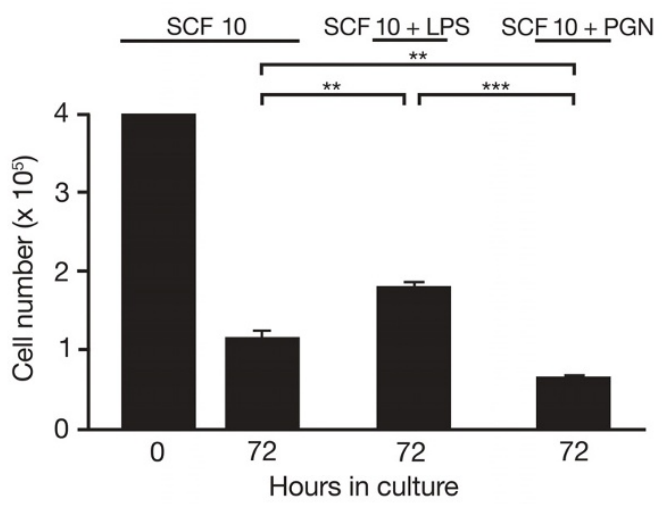

B

\section{SCF 100}
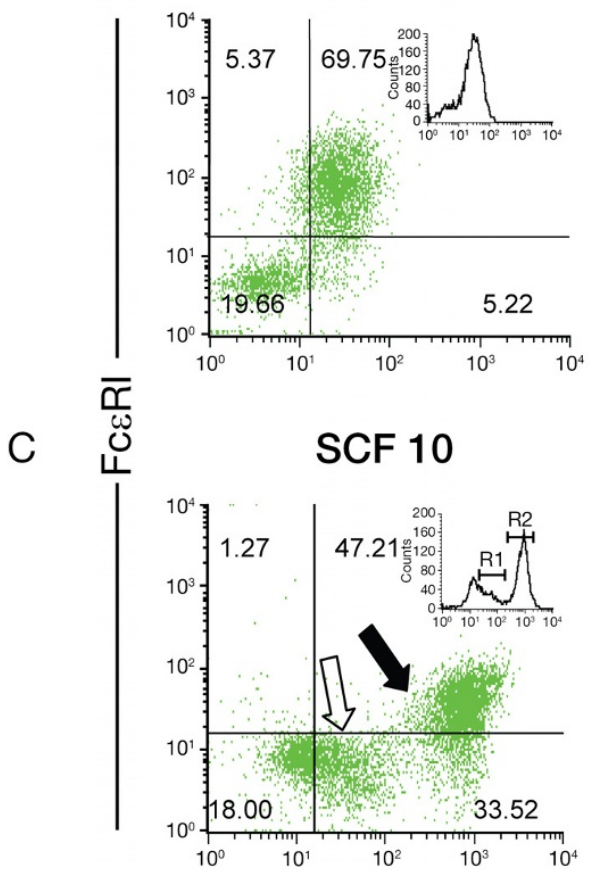

SCF 100 + LPS

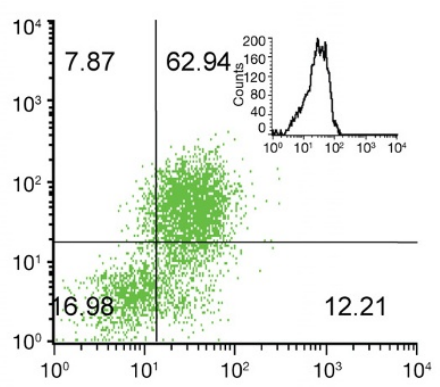

SCF $10+$ LPS

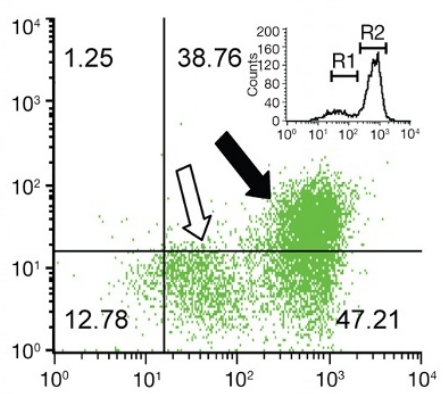

SCF $100+$ PGN

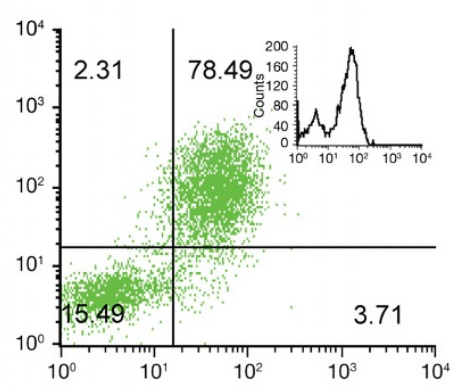

SCF $10+$ PGN

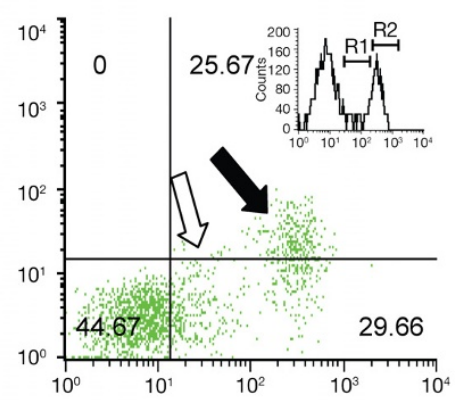

CD117

Figure 2

\section{Figure 2}

FACS analysis of 8 wk Fc\&RI ${ }^{+} / C D I I 7^{+}$HuMC cultured in rhSCF alone, with LPS or PGN. A) HuMC numbers following culture for $72 \mathrm{hr}$ in $10 \mathrm{ng} / \mathrm{ml}$ rhSCF alone and with $100 \mathrm{ng} / \mathrm{ml}$ LPS or $10 \mu \mathrm{g} / \mathrm{ml}$ PGN. Results are shown as the means \pm SEM of 3 separate experiments performed in duplicate; B and C) Representative dot plots of HuMC expression of Fc\&RI (vertical axis) and CDI 17 (horizontal axis) following culture for $72 \mathrm{hr}$ in $100 \mathrm{ng} / \mathrm{ml}$ (B) or $10 \mathrm{ng} / \mathrm{ml}$ (C) rhSCF (left-side plots), rhSCF and $100 \mathrm{ng} / \mathrm{ml}$ LPS (middle plots), and rhSCF and $10 \mu \mathrm{g} / \mathrm{ml} \mathrm{PGN} \mathrm{(right-side} \mathrm{plots)} \mathrm{In} \mathrm{C,} \mathrm{CDI} \mathrm{I} \mathrm{7low} \mathrm{(open} \mathrm{arrows;} \mathrm{insert}$ RI histogram) and CDI I 7 high (solid arrows; insert R2 histogram) are labeled. Representative dot plots are shown of $n=3$ separate experiments performed in duplicate.

HuMC was downregulated by the presence of LPS, while PGN in the presence of $10 \mathrm{ng} / \mathrm{ml}$ rhSCF again inhibited HuMC numbers. Due to the inhibition of HuMC growth and development by TLR2 agonists PGN and LTA, the remaining experiments focused on LPS and its HuMC growth and survival enhancing effects. 
Effect of LPS on 8 wk old HuMC $\beta$-hex, PGD 2 and LTC release in short-term cultures

We next proceeded to characterize the effect of LPS over $72 \mathrm{hr}$ on HuMC, which had been in culture for $8 \mathrm{wks}$, as to histamine content; and $\beta$-hex, $\mathrm{PGD}_{2}$ and $\mathrm{LTC}_{4}$ release. In the presence of $10 \mathrm{ng} / \mathrm{ml} \mathrm{rhSCF}$, the addition of 100 $\mathrm{ng} / \mathrm{ml}$ LPS increased the histamine content of HuMC over $72 \mathrm{hrs}$ from a mean of $7.83 \pm 2.33 \mathrm{pg} /$ cell to $12.75 \pm 1.94$ $\mathrm{pg} /$ cell $(\mathrm{n}=3, \mathrm{p}<0.05)$. We next assayed release and found that the addition of $100 \mathrm{ng} / \mathrm{ml} \mathrm{LPS} \mathrm{to} 10 \mathrm{ng} / \mathrm{ml}$ rhSCF over 72 hrs decreased $\beta$-hex release following FceRI crosslinking from $12.21 \pm 0.31 \%$ to $3.56 \pm 1.35 \%(\mathrm{n}=3$, $\mathrm{p}<0.01)$. Following FceRI crosslinking, LPS did not alter $\mathrm{PGD}_{2}$ and $\mathrm{LTC}_{4}$ release $(13.48 \pm 0.52 \mathrm{ng} / \mathrm{ml}$ and $11.26 \pm$ $4.75 \mathrm{ng} / \mathrm{ml}$, respectively). Thus, the addition of LPS to HuMC cultured over $72 \mathrm{hr}$ with $10 \mathrm{ng} / \mathrm{ml}$ rhSCF reduced $\% \beta$-hex release, but had no effect on $\mathrm{PGD}_{2}$ and $\mathrm{LTC}_{4}$ release.

\section{Effect of LPS on 8 wk HuMC protease expression and composition in short-term cultures}

We next examined the effect of LPS on $8 \mathrm{wk}$ old HuMC protease expression and composition over 72 hrs. In the presence of $10 \mathrm{ng} / \mathrm{ml} \mathrm{rhSCF}$ and $100 \mathrm{ng} / \mathrm{ml} \mathrm{LPS,} \mathrm{FACS}$ analysis showed significant increases in tryptase+, chymase+, carboxypeptidase+, tryptase+/chymase+ and tryptase+/carboxypeptidase+ HuMCs ( $\mathrm{n}=3$, p < 0.01) (Fig. $3 \mathrm{~A}$, left) compared to cultures with $10 \mathrm{ng} / \mathrm{ml} \mathrm{rhSCF}$ only. This effect was not observed when cells were cultured in $100 \mathrm{ng} / \mathrm{ml}$ of rhSCF (Fig. 3A; compare right with left). As shown in Figure 3B, live gate analysis of the CD117low (region R1) and CD117high (region R2) HuMC subpopulations, cultured in the presence of $10 \mathrm{ng} / \mathrm{ml} \mathrm{rhSCF}$ with and without $100 \mathrm{ng} / \mathrm{ml}$ LPS, determined that increases in chymase and carboxypeptidase staining were detected predominately for the CD117low(region R1) subpopulation.

\section{Effect of LPS and PGN on 8 wk old HuMC cytokine release and the effect of cytokines on protease expression}

Since mature $8 \mathrm{wk}$ HuMC cultures do not contain other cell types, we next asked whether the effect of LPS on protease expression might be induced through endogenous HuMC cytokine release. To this end, cell culture supernatants harvested from HuMC cultures following $72 \mathrm{hr}$ incubation with 10 or $100 \mathrm{ng} / \mathrm{ml}$ rhSCF alone, or with $100 \mathrm{ng} /$ $\mathrm{ml}$ LPS were assayed for the presence of IL-1 $\beta$, IL-2, IL-4, IL-6, IL-8, IL-10, IL-12, IFN- $\gamma$, SCF and TNF- $\alpha$. As shown in Figure 4A, $100 \mathrm{ng} / \mathrm{ml}$ LPS induced HuMC to produce IL-1 $\beta$, IL-6, IL- 8 and IL-12, with no differences noted using 10 or $100 \mathrm{ng} / \mathrm{ml}$ rhSCF $(\mathrm{n}=3, \mathrm{p}<0.05)$. No elevations in IL-2, IL-4, IL-10, IFN- $\gamma$ and TNF- $\alpha$ were noted in the presence of LPS. As expected, SCF was detected in cultures containing SCF and LPS, but levels were not elevated above those measured in cultures with SCF alone. In addi- tion, no elevations in cytokines were noted in cultures to which PGN had been added.

To determine if observed increases in tryptase, chymase and carboxypeptidase expression could be explained on the basis of endogenous IL-1 $\beta$, IL- 6 , IL- 8 and IL-12 release, HuMC were cultured with rhSCF 10 or $100 \mathrm{ng} / \mathrm{ml}$ alone or with rhIL-1 $\beta$, rhIL-6, rhIL- 8 and rhIL-12 individually or as a four-cytokine mixture, using concentrations of cytokines detected by immunoassay in the culture supernatants (Fig. 4B). The combination of $10 \mathrm{ng} / \mathrm{ml} \mathrm{rhSCF}$ with either IL- $1 \beta$ or IL- 6 gave rise to significant increases in tryptase+, chymase+, tryptase+/chymase+ and tryptase+/carboxypeptidase+ HuMCs, in contrast to rhIL- 8 or rhIL-12 which did not increase tryptase, chymase and carboxypeptidase expression (data not shown). No increases in protease expression were observed in the presence of $100 \mathrm{ng} / \mathrm{ml} \mathrm{rhSCF}$ with other cytokines. A combination of $10 \mathrm{ng} / \mathrm{ml} \mathrm{rhSCF}$ with $150 \mathrm{pg} / \mathrm{ml} \mathrm{rhIL}-1 \beta, 25 \mathrm{pg} / \mathrm{ml} \mathrm{rhIL}-6$, $5000 \mathrm{pg} / \mathrm{ml} \mathrm{rhIL}-8$ and $25 \mathrm{pg} / \mathrm{ml}$ rhIL-12, cytokine concentrations detected in the cell cultures supernatant following $72 \mathrm{hr}$ of incubation with $100 \mathrm{ng} / \mathrm{ml}$ LPS, gave rise to increased tryptase + , chymase + , carboxypeptidase $+(\mathrm{n}=$ 3 , p < 0.01), tryptase+/chymase+ and tryptase+/carboxypeptidase+ $(\mathrm{n}=3, \mathrm{p}<0.05)$ HuMC numbers, reproducing the observed increases seen with $100 \mathrm{ng} / \mathrm{ml}$ LPS and $10 \mathrm{ng} / \mathrm{ml} \mathrm{SCF}$ (Fig. 4B, left-sided graph). Furthermore, this effect of LPS could be significantly reduced when HuMC were cultured for $72 \mathrm{hr}$ in the added presence of $0.5 \mu \mathrm{g} / \mathrm{ml}$ anti-IL- $1 \beta$ and $1.0 \mu \mathrm{g} / \mathrm{ml}$ anti-IL-6 antibodies (Fig. 4B, right-sided graph). QPCR analysis of HuMC cells showed an overall 8-fold increase in tryptase and 20-fold increase in chymase expression, following stimulation for $72 \mathrm{hr}$ with $10 \mathrm{ng} / \mathrm{ml} \mathrm{rhSCF}, 150 \mathrm{pg} / \mathrm{ml} \mathrm{rhIL}-1 \beta, 25 \mathrm{pg} / \mathrm{ml}$ rhIL-6, $5000 \mathrm{pg} / \mathrm{ml}$ rhIL-8 and $25 \mathrm{pg} / \mathrm{ml}$ rhIL-12 (Fig. 4C). Similar increases in tryptase and chymase expression were noted following stimulation for $72 \mathrm{hr}$ with $10 \mathrm{ng} / \mathrm{ml}$ rhSCF and $100 \mathrm{ng} / \mathrm{ml}$ LPS (Fig. 4C, right-sided graph). Together, this data is consistent with the conclusion that LPS stimulates HuMC in culture to release IL-1 $\beta$, IL-6, IL8 and IL-12, and the overall net effect is to increase CD117low HuMC production of tryptase, chymase and carboxypeptidase.

\section{Effect of LPS on 4-6 wk old WT and TLR4 KO BMMC protease mRNA expression in short-term culture}

Since short-term exposure to LPS increased protease expression in HuMC, we asked whether short-term exposure to LPS could also effect the protease mRNA expression of BMMC from WT (C57BL/6) mice. Thus, BMMC were first allowed to mature over $4-6$ wks, washed and cultured in either 3 or $30 \mathrm{ng} / \mathrm{ml} \mathrm{rmIL-3,} 10$ or $50 \mathrm{ng} / \mathrm{ml}$ rmSCF alone and with $100 \mathrm{ng} / \mathrm{ml}$ LPS for $72 \mathrm{hr}$. BMMC were then harvested and examined by QPCR for MMCP mRNA expression. WT BMMC had constitutive mRNA 


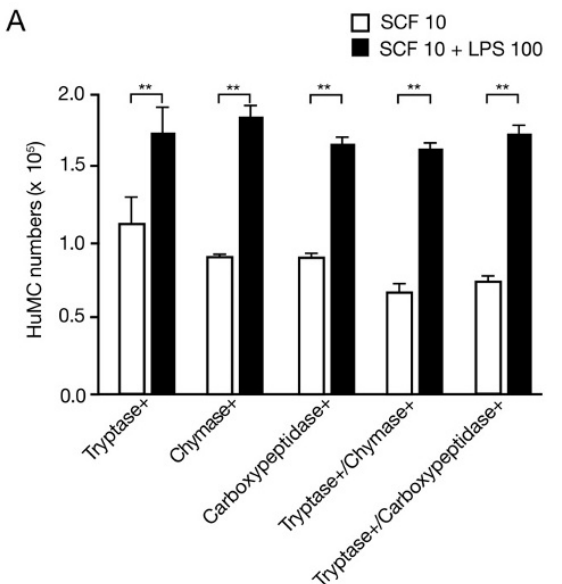

B

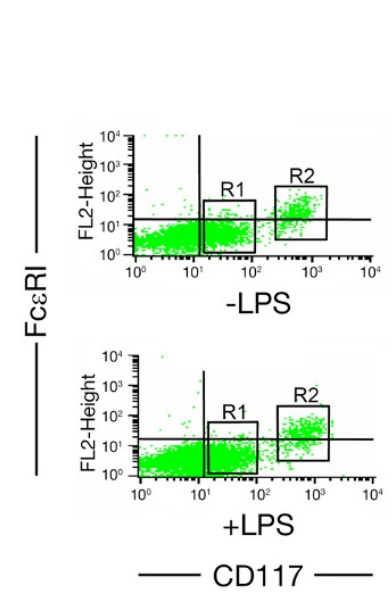

CD117
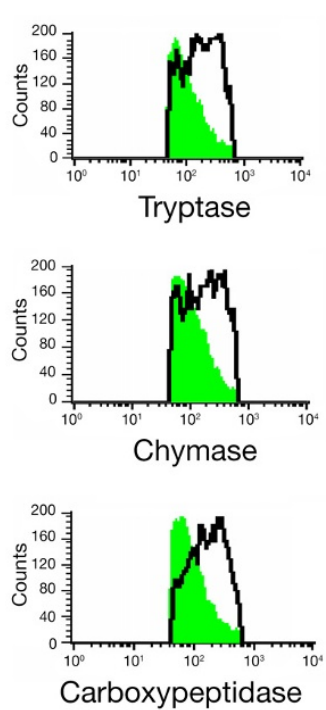

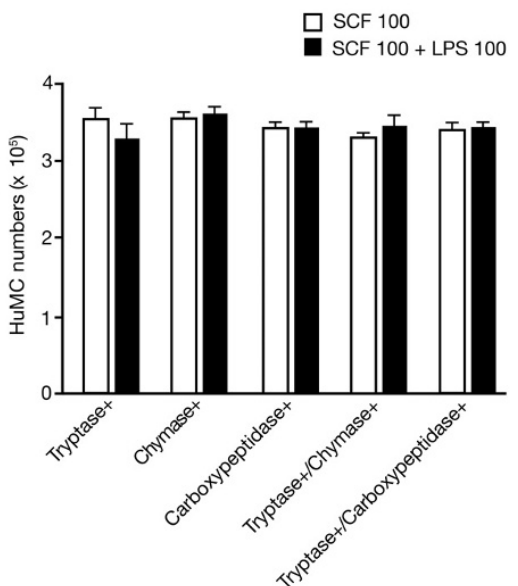

CD117 $7^{\text {high }}$
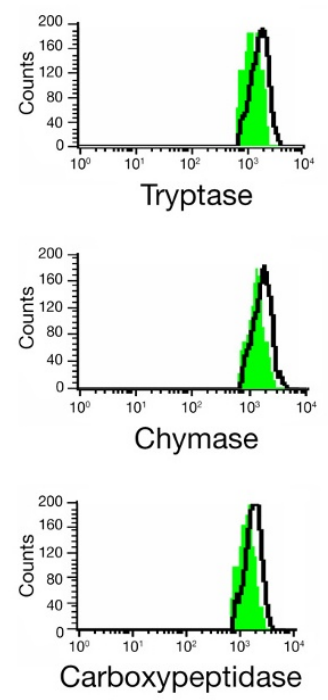

Figure 3

Figure 3

Tryptase, chymase and carboxypeptidase expression of 8 wk HuMC cultured in rhSCF alone and with $100 \mathrm{ng} /$ mI LPS; Live gate analysis of CDI I $7^{\text {low }}$ (RI region) and CDI I $7_{\text {high }}$ (R2 region) cells. A) Left-sided graph - HuMC numbers expressing tryptase, chymase, and carboxypeptidase following culture for $72 \mathrm{hr}$ in $10 \mathrm{ng} / \mathrm{ml} \mathrm{rhSCF}$ alone, and with 100 $\mathrm{ng} / \mathrm{ml} \mathrm{LPS}$. For $10 \mathrm{ng} / \mathrm{ml}$ rhSCF alone, the mean \pm SEM of percentages of protease positive HuMC are: tryptase $88.5 \mathrm{I} \pm 5.30 \%$, chymase $91.34 \pm 1.62 \%$, carboxypeptidase $91.53 \pm 1.20 \%$, tryptase/chymase $83.75 \pm 4.61 \%$ and tryptase/carboxypeptidase $87.32 \pm 4.90 \%$. For $10 \mathrm{ng} / \mathrm{ml}$ rhSCF and LPS, the mean \pm SEM of percentages of protease positive HuMC cells are: tryptase $92.50 \pm 2.32 \%$, chymase $96.30 \pm 0.75 \%$, carboxypeptidase $94.43 \pm 4.21 \%$, tryptase/chymase $92.33 \pm 3.85 \%$, and tryptase/carboxypeptidase $90.50 \pm 2.30 \%$. Right-sided graph - $100 \mathrm{ng} / \mathrm{ml} \mathrm{rhSCF}$ alone, and with $100 \mathrm{ng} / \mathrm{ml}$ LPS. For $100 \mathrm{ng} / \mathrm{ml} \mathrm{rhSCF}$ alone, the mean \pm SEM of percentages of protease positive HuMC are: tryptase $94.56 \pm 2.30 \%$, chymase $93.30 \pm 1.38 \%$, carboxypeptidase $88.50 \pm 3.21 \%$, tryptase/chymase $88.70 \pm 5.41 \%$, and tryptase/carboxypeptidase $88.55 \pm 3.83 \%$. For $100 \mathrm{ng} / \mathrm{ml} \mathrm{rhSCF}$ and LPS, the mean \pm SEM of percentages of protease positive HuMC are: tryptase $92.57 \pm 3.30 \%$, chymase $95.33 \pm 0.85 \%$, carboxypeptidase $89.8 \mathrm{I} \pm 3.90 \%$, tryptase/chymase $93.63 \pm 3.25 \%$, and tryptase/carboxypeptidase $89.50 \pm 5.42 \%$. Results are shown as the mean \pm SEM of 3 separate experiments performed in duplicate; B) Representative dot plots and histograms of CDI I 7 low ( $R$ I region) and $C D I I 7$ high (R2 region) cells analyzed for $F c \varepsilon R I, C D I I 7$, tryptase, chymase and carboxypeptidase expression during culture in $10 \mathrm{ng} / \mathrm{ml}$ rhSCF alone and with $100 \mathrm{ng} / \mathrm{ml}$ LPS (as seen in Figure A, left). In the histograms, horizontal axis represents PE or PE5.5-conjugated markers analyzed; vertical axis represents total cell numbers analyzed. Cultures with $10 \mathrm{ng} / \mathrm{ml}$ rhSCF alone are shown by the shaded areas. Representative dot plots and histograms are shown of $n=3$ separate experiments performed in duplicate. 
expression for the proteases MMCP-4, -5, -6 and CPA3 when cultured in either rmIL-3 (3-30 ng/ml) or rmSCF (10-50 ng/ml) for $72 \mathrm{hr}$ (data not shown). As shown in Figure 5, following the addition of LPS for $72 \mathrm{hr}$, an upregulation in MMCP-1, MMCP-2 and MMCP-4 mRNA expression was observed in the presence of either rmIL3 (3 ng/ml) (Fig. 5A) or in the presence of rmSCF (10 ng/ $\mathrm{ml}$ ) (Fig. 5B). A similar pattern of MMCP upregulation was also observed at the higher concentrations of rmIL3 (30 $\mathrm{ng} / \mathrm{ml}$ ) or $\mathrm{rmSCF}(50 \mathrm{ng} / \mathrm{ml})$ in the presence of LPS (data not shown). Since TLR4 deficient mice are hyporesponsive to lipopolysaccharide [8], and to determine if upregulated MMCP levels by LPS were mediated by TLR4, we obtained BMMC from WT C3H/HeOuJ and TLR4 KO $\mathrm{C} 3 \mathrm{H} / \mathrm{HeJ}$ mice and exposed them to low concentrations of cytokine in combination with LPS. As can be seen, in the presence of either rmIL-3 (3 ng/ml) (Fig. 5C) or rmSCF $(10 \mathrm{ng} / \mathrm{ml}$ ) (Fig. 5D), WT BMMC from $\mathrm{C} 3 \mathrm{H} /$ $\mathrm{HeOuJ}$ mice had a similar MMCP mRNA profile in response to LPS as WT BMMC from C57BL/6 mice. However, in contrast with $\mathrm{C} 3 \mathrm{H} / \mathrm{HeOuJ}, \mathrm{BMMC}$ cultured from $\mathrm{C} 3 \mathrm{H} / \mathrm{HeJ}$ mice and incubated with mIL-3 (3 ng/ml) (Fig. $5 \mathrm{C}$; compare with $5 \mathrm{~A}$ ), or $\mathrm{rmSCF}$ (10 ng/ml) (Fig. 5D; compare with 5B) had reduced MMCP-1, MMCP-2 and MMCP-4 mRNA expression following incubation with LPS. BMMC from both WT and TLR2 KO mice were also cultured in the presence of rmIL-3 (3 ng/ml) or rmSCF (10 $\mathrm{ng} / \mathrm{ml}$ ) with PGN or LTA for $72 \mathrm{hr}$, and examined for any effect on protease mRNA expression. As shown in Figures 5E-H, neither TLR2 ligand affected MMCP expression in WT or TLR2 KO mice. Taken together these data suggest that LPS, but not the TLR2 ligands PGN or LTA, induce the upregulation of MMCP-1, -2 and -4 mRNA expression in BMMC through cytokines which are produced by mast cell activation through TLR4.

\section{Discussion}

In this report, we demonstrate that LPS and PGN have very different and specific effects on progenitor and mature HuMC. These observations are relevant, since HuMC maturation may occur in proximity to tissues such as the lung and gastrointestinal mucosa that interface with the external environment, where HuMC progenitors and their mature counterparts may variably be exposed to bacterial-derived products over time. It has been shown, for example, that inhalation of aerosolized LPS exacerbates allergic airway inflammation in the mouse experimental asthma model through TLR4-mediated mast cell activation and promotion of $\mathrm{T}_{\mathrm{H}} 2$ responses [9]. Cell transfer experiments using TLR4 KO mast cells confirmed that the effect of LPS is mediated through TLR4 on mast cells, consistent with our data. We also found that HuMCs in the presence of LPS synthesized de novo IL-1 $\beta$ and IL-12, in addition to IL-6 and IL-8, which is consistent with the induction of $\mathrm{T}_{\mathrm{H}} 1$ effector responses reported for mouse dendritic cell (DC) cultures [10]. If the hypothesis put forward that, under experimental conditions, toll-mediated events facilitate the generation of $\mathrm{T}_{\mathrm{H}} 1$ responses [10], then mouse and human in vitro mast cell data are in agreement, and in vivo inhalation of aerosolized LPS might induce both HuMC and DC to produce increased cytokine levels that lead to the promotion of $\mathrm{T}_{\mathrm{H}} 1$-skewed responses. The net effect of these $\mathrm{T}_{\mathrm{H}} 1$ responses in combination with LPSinduced $\mathrm{T}_{\mathrm{H}} 2$ responses would determine the overall extent of allergic airway inflammation.

We thus examined $\mathrm{CD}^{2} 4^{+}$-derived HuMC progenitors over 6 wks (long-term cultures) and 8 wk mature HuMC over $72 \mathrm{hr}$ (short-term cultures) for the effect of LPS, PGN and LTA on cell numbers; and CD117, FceRI, cytokine, tryptase, chymase and carboxypeptidase expression. In continuous culture over 6 wks, LPS had little or no effect on HuMC numbers, while PGN led to a decrease in HuMC numbers at all concentrations (Fig. 1). LTA, another TLR2 agonist, also decreased HuMC numbers at the highest concentrations. LPS, but not PGN, led to small increases in CD117, tryptase and chymase expression compared with rhSCF alone, while decreasing FceRI expression (data not shown).

These differential effects of LPS and PGN became more evident when mature $8 \mathrm{wk}$ HuMC were used in short-term cultures. When $8 \mathrm{wk} \mathrm{HuMC}$, originating from CD $34^{+}$cells in rhSCF, were cultured with PGN and $10 \mathrm{ng} / \mathrm{ml} \mathrm{rhSCF}$ for $72 \mathrm{hr}, \mathrm{PGN}$ reduced HuMC numbers below those observed with $10 \mathrm{ng} / \mathrm{ml}$ rhSCF alone. PGN had no effect on HuMC numbers when $100 \mathrm{ng} / \mathrm{ml}$ rhSCF was used. LPS somewhat enhanced HuMC numbers in the presence of $10 \mathrm{ng} / \mathrm{ml} \mathrm{rhSCF}$. FceRI expression was again reduced in cultures containing either 10 or $100 \mathrm{ng} / \mathrm{ml} \mathrm{rhSCF}$ and LPS (Fig. 2), consistent with the observation that the LTA, following ligation with TLR2, reduced surface expression of FceRI in isolated human pulmonary mast cells [11]. In the presence of $10 \mathrm{ng} / \mathrm{ml} \mathrm{rhSCF}$, the reduction in FceRI expression could be seen to affect two CD117 subpopulations: CD117 low and CD117 high HuMCs (Fig. 2B). The MFI of the CD117high cells increased a log-fold higher, suggesting that $100 \mathrm{ng} / \mathrm{ml}$ of rhSCF suppressed CD117 expression on HuMC, consistent with other reports [12]. In the presence of LPS and $10 \mathrm{ng} / \mathrm{ml}$, but not $100 \mathrm{ng} / \mathrm{ml}$ of rhSCF, tryptase positive HuMC co-expressing chymase and carboxypeptidase increased (Fig. 3A), and live gate analysis showed that increases in tryptase, chymase and carboxypeptidase occurred predominately in the CD117 low subpopulation (Fig. 3B). These data therefore demonstrate that shortterm exposure of mature HuMC to varying concentrations of rhSCF alters CD117 expression [12], and protease expression; and that these effects are modulated by LPS. Of note is that $100 \mathrm{ng} / \mathrm{ml} \mathrm{rhSCF}$ that we and others use for 

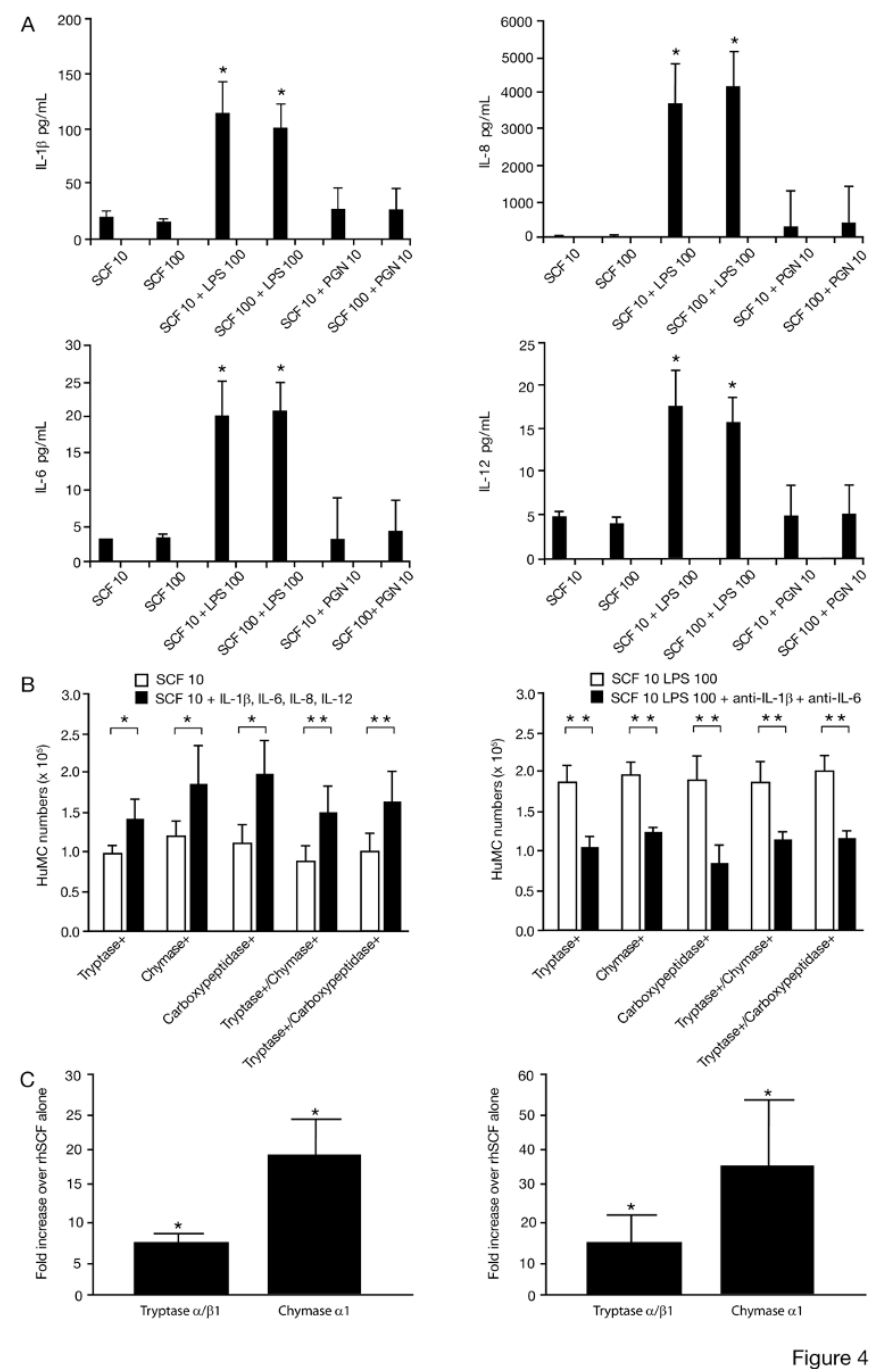

Figure 4

Immunoassay of cytokine release and cytokine effect on tryptase, chymase, and carboxypeptidase expression of 8 wk HuMC by FACS and QPCR. Effect of rhIL-I $\beta$ and rhIL-6 blocking antibodies. A) Immunoassay for the presence of IL-I $\beta$, IL-6, IL-8, IL- I 2 and SCF in supernatants of 8 wk HuMC treated for $72 \mathrm{hr}$ with rhSCF, rhSCF and LPS, and rhSCF and PGN; B) Left-sided graph - HuMC numbers expressing tryptase, chymase, and carboxypeptidase following 72 hr in culture

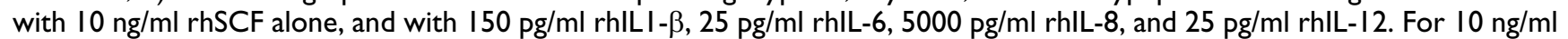
rhSCF alone, the mean \pm SEM of percentages of protease positive HuMC are: tryptase $91.50 \pm 3.13 \%$, chymase $92.20 \pm 3.11 \%$, carboxypeptidase $95.73 \pm 1.86 \%$, tryptase/chymase $87.32 \pm 3.76 \%$ and tryptase/carboxypeptidase $85.70 \pm 4.77 \%$. For $10 \mathrm{ng} / \mathrm{ml}$ rhSCF and rhILI- $\beta$, rhlL-6, rhIL-8, and rhIL-12, the mean \pm SEM of percentages of protease positive HuMC are: tryptase 94.99 $\pm 0.83 \%$, chymase $97.23 \pm 0.35 \%$, carboxypeptidase $97.62 \pm 0.50 \%$, tryptase/chymase $89.93 \pm 3.87 \%$ and tryptase/carboxypeptidase $89.80 \pm 4.23 \%$. Results are shown as the mean \pm SEM of 3 separate experiments performed in duplicate. Right-sided graph - HuMC numbers expressing tryptase, chymase, and carboxypeptidase following $72 \mathrm{hr}$ in culture with $10 \mathrm{ng} / \mathrm{ml} \mathrm{rhSCF}$ and 100 $\mathrm{ng} / \mathrm{ml}$ LPS, and with $0.5 \mu \mathrm{g} / \mathrm{ml}$ anti-rhIL-I $\beta$ and I $\mu \mathrm{g} / \mathrm{ml}$ anti-rhlL-6. Goat blocking antibodies are matched with goat isotype IgG control. For $10 \mathrm{ng} / \mathrm{ml} \mathrm{rhSCF}$ and LPS, the mean \pm SEM of percentages of protease positive HuMC are: tryptase $92.30 \pm 1.30 \%$, chymase $98.22 \pm 0.35 \%$, carboxypeptidase $95.53 \pm 1.22 \%$, tryptase/chymase $91.40 \pm 2.77 \%$, and tryptase/carboxypeptidase $91.43 \pm 1.91 \%$. For $10 \mathrm{ng} / \mathrm{ml}$ rhSCF, LPS, anti-rhIL-I $\beta$ and anti-rhIL-6, the mean \pm SEM of percentages of protease positive HuMC are: tryptase $90.60 \pm 1.37 \%$, chymase $94.71 \pm 0.45 \%$, carboxypeptidase $92.12 \pm 1.22 \%$, tryptase/chymase $88.30 \pm 2.31 \%$, and tryptase/carboxypeptidase $87.1 \mathrm{II} \pm 3.05 \%$. Results are shown as the mean \pm SEM of 2 separate experiments performed in duplicate. C) Left-sided graph - QPCR for tryptase and chymase expression of HuMC cultured with rhSCF alone, and with ILI $\beta$, IL-6, IL-8 and IL-12; Right-sided graph - QPCR for tryptase and chymase expression of HuMC cultured with rhSCF alone, and with LPS. Results are shown as the fold increase over rhSCF alone, and are the mean \pm SEM of $n=3$ separate experiments performed in triplicate. 
optimal HuMC in vitro growth may mask the upregulatory effects of LPS, when LPS is added to cultures.

It has been reported that activation of murine mast $[13,14]$ and dendritic $[15]$ cells through TLRs augments production of inflammatory cytokines, and that cytokines can influence human mast cell protease expression $[16,17]$. To determine whether LPS-driven short-term cultures induced HuMC-derived cytokine production which in turn could influence cell survival as well as changes in surface receptor and protease expression, we assayed short-term cultures and found, as noted above, significant levels of IL-1 $\beta$, IL-6, IL-8 and IL-12 in LPS-driven, but not PGN-driven, cultures. Furthermore, we were able to reproduce the effects of LPS on HuMC by culturing these cells in $10 \mathrm{ng} / \mathrm{ml}$ rhSCF and immunoassay-detected concentrations of IL-1 $\beta$, IL-6, IL-8 and IL-12 (Fig. 4B). The combination of $10 \mathrm{ng} / \mathrm{ml}$ rhSCF with either IL-1 $\beta$ or IL- 6 , but not IL-8 or IL-12, also reproduced the LPS observed effects in short-term cultures. Thus, one possible mechanism of action of LPS is to stimulate production of mature HuMCderived IL- $1 \beta$ and IL- 6 , which together promote HuMC survival, alter HuMC FceRI and protease expression, and together with IL-12 direct HuMC involvement in resolving innate immunity and promoting acquired immune responses. This transition from innate to acquired immunity involves the resolution of an inflammatory event, and as demonstrated in mouse models, IL- 6 is involved in reducing bacteria-induced inflammation [18-20]. In addition, although IL-8 was not shown to affect HuMC survival, surface receptor and protease expression, IL-8 production by HuMC might in part explain how LPS can promote neutrophil influx into inflammatory sites and promote host defense mechanisms.

The conclusion that LPS upregulates HuMC protease expression and composition were further supported using BMMC from WT and TLR4 KO mice (Fig. 5). It is known that exposure of WT BMMC to rmIL3 and rmSCF alters the protease composition of these cells [21]. Following exposure of WT BMMC to reduced concentrations of rmIL-3 or rmSCF in the presence of LPS an increase in mRNA for the MMCP-1, -2 and -4 was observed. BMMC from TLR4 KO mice, following stimulation with LPS, failed to show any alteration in MMCP-1, MMCP-2, and MMCP-4 mRNA expression compared with WT controls. These findings demonstrate that the differential mRNA expression of MMCP depends on the presence and concentration of rmIL-3 or rmSCF used to culture BMMC, and that the MMCP mRNA expression of BMMC can be influenced by LPS ligation with TLR4, an effect which is eliminated in the absence of a functional TLR4 receptor. MMCP-1 mRNA expression in mucosal mast cells of Trichinella spiralis-infected mice can similarly be influenced by IL-10 [22]. Furthermore, MMCP-1, MMCP-2 and MMCP-4 are chymases, and MMCP-4 most probably represents the murine homolog of human chymase [23]. In addition, the observation that TLR2 ligands PGN and LTA had no effect on MMCP mRNA expression from WT and TLR2 KO-derived BMMC appears to be consistent with the observation in HuMC (Figure 4) that LPS, but not PGN, increases HuMC numbers and protease expression, and may be related to the LPS-induced increase in IL-1 $\beta$ and IL-6.

The upregulation of human chymase and carboxypeptidase by LPS may be another means by which mast cells participate in endotoxin-driven alteration in $\mathrm{T}_{\mathrm{H}} 1$ and $\mathrm{T}_{\mathrm{H}} 2$ responses. Mast cell-derived chymase and carboxypeptidase are involved in resistance to toxic endogenous or exogenous peptides such as endothelin-1 [24] and venoms [25] respectively; thus, their induction may counterbalance the effect of tryptase which is known to increase T cell-derived IL-13 and airway hyper-responsiveness [26].

\section{Conclusion}

Taken together, these data demonstrate that LPS can alter HuMC numbers, influence cytokine and protease expression and composition, and that the effect of LPS is best observed when reduced concentrations of rhSCF are used, as may occur in tissues. These data further support the idea that the appearance of LPS during a gram negative bacterial infection, in the presence of tissue concentrations of SCF, may induce tissue mast cells to express a unique composition of proteases beneficial for controlling and eliminating this particular infection. In other infections or clinical states having higher concentrations of other cytokines and/or the presence of other mediators, tissue mast cell progenitors may differentially develop and express specific surface receptors and proteases which enable these mast cells to more effectively participate in innate immune responses.

\section{Methods CD34+ immunoselection}

Peripheral blood (PB) mononuclear cells collected by leukapheresis were obtained from normal volunteers following informed consent [1]. CD34+ progenitor cells were enriched to $95-99 \%$ by positive immunomagnetic selection or using commercially available affinity columns.

\section{HuMC long-term and short-term cultures Long-term cultures}

Peripheral blood CD $34^{+}$cells were placed at a concentration of $5 \times 10^{4}$ cells $/ \mathrm{ml}$ in serum-free media (SFM) (StemPro-34 SFM; Life Technologies, Grand Island, NY) supplemented with $2 \mathrm{mM}$ L-glutamine, $100 \mathrm{IU} / \mathrm{ml}$ penicillin, $50 \mu \mathrm{g} / \mathrm{ml}$ streptomycin (complete SFM) and 100 $\mathrm{ng} / \mathrm{ml}$ recombinant human stem cell factor (rhSCF) (Peprotech, Rocky Hill, NJ) alone or in combination with 
A

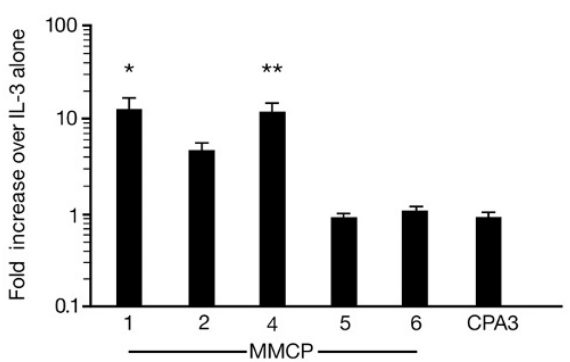

C

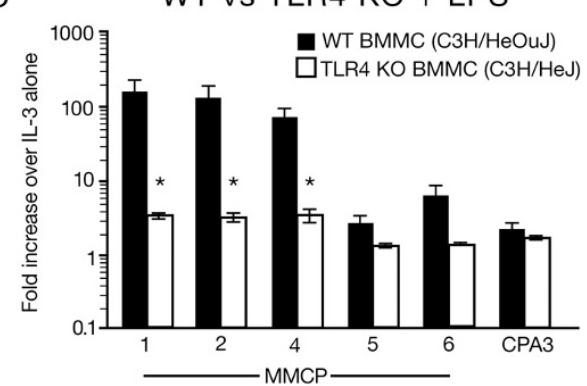

E

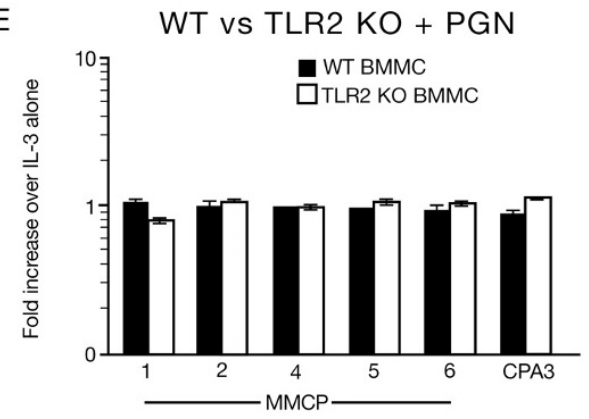

G

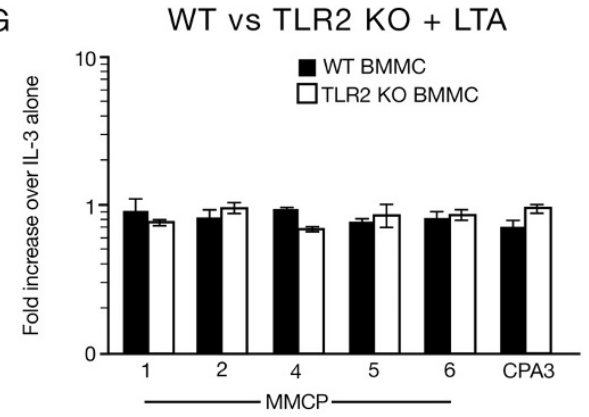

B

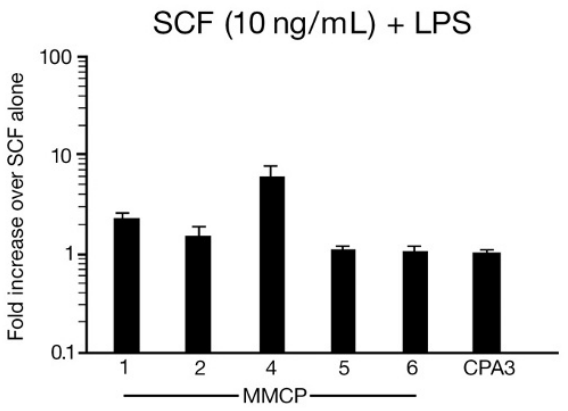

D

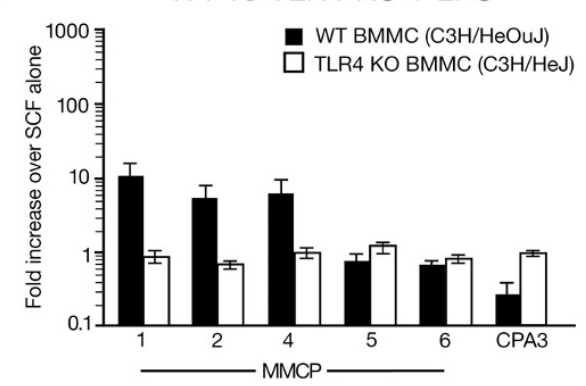

F

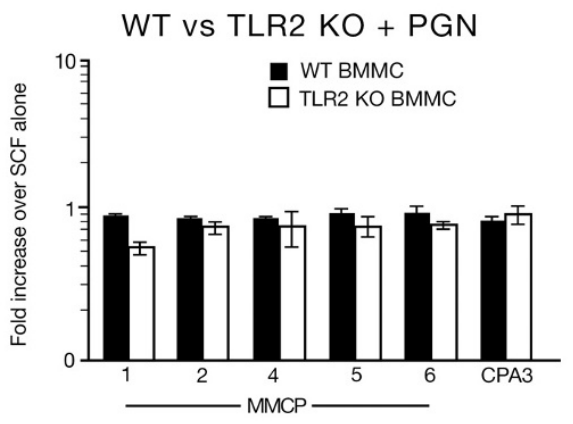

$\mathrm{H}$

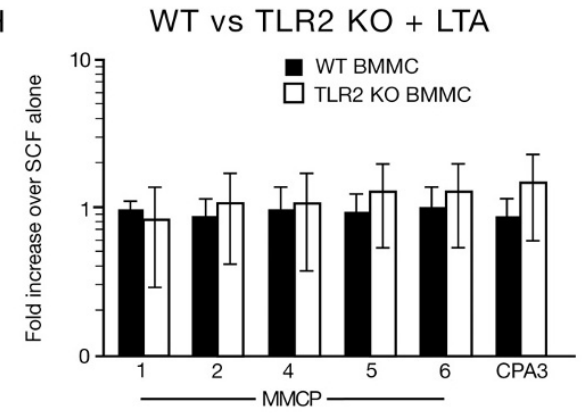

Figure 5

Figure 5

Protease mRNA expression by WT, TLR4 KO and TLR2 KO BMMC in the presence of LPS, PGN or LTA and either rmIL-3 or rmSCF. MMCP-I [I], MMCP-2 [2], MMCP-4 [4], MMCP-5 [5], MMCP-6 [6] and carboxypeptidase A (CPA3) were analyzed by real-time PCR from 4-6 wk WT (C57BL/6) BMMC (A-B), WT (C3H/HeOuJ), TLR4 KO (C3H/HeJ) BMMC (C-D), and WT, TLR2 KO BMMC (E-H). BMMC were cultured for $72 \mathrm{hr}$ with either $3 \mathrm{ng} / \mathrm{ml} \mathrm{rmlL}-3$ (A, C, E, G) or 10 $\mathrm{ng} / \mathrm{ml} \mathrm{rmSCF}(\mathrm{B}, \mathrm{D}, \mathrm{F}, \mathrm{H})$ in the absence or presence of $100 \mathrm{ng} / \mathrm{ml}$ LPS, $10 \mu \mathrm{g} / \mathrm{ml}$ PGN or I $\mu \mathrm{g} / \mathrm{ml}$ LTA. The effect of LPS, PGN or LTA on protease mRNA expression was determined by calculating the fold increase compared to untreated control (C57BL/6 or $\mathrm{C} 3 \mathrm{H} / \mathrm{HeOuJ}$ ) samples. Results shown are mean $\pm \mathrm{SEM}, \mathrm{n}=4$ in triplicate for WT BMMC $(A-B), n=3$ in triplicate for WT and TLR4 KO BMMC (C-D), and $n=2$ in triplicate for WT and TLR2 KO BMMC (E-H). 
either 10-1000 ng/ml LPS (Sigma-Aldrich, St. Louis, $\mathrm{MO}$ ), $10-1000 \mu \mathrm{g} / \mathrm{ml}$ PGN (Fluka, Ronkonkoma, NY) or $0.1-10 \mu \mathrm{g} / \mathrm{ml}$ LTA (Invivogen, San Diego, CA). Heat inactivated human serum was added to cultures containing LPS. Cells were counted and stained weekly with Kimura's stain and tested for tryptase positivity to determine total cell and HuMC numbers as described [1,27]. Kimura's and tryptase staining of HuMC did not differ by greater than 5\%. Cytokines and TLR ligands were replaced weekly. Short term cultures: Eight wk HuMC were cultured in $100 \mathrm{ng} / \mathrm{ml} \mathrm{rhSCF}$, washed and then incubated for $72 \mathrm{hr}$ with either 10 or $100 \mathrm{ng} / \mathrm{ml}$ rhSCF alone, or in combination with either $100 \mathrm{ng} / \mathrm{ml}$ LPS or $10 \mu \mathrm{g} / \mathrm{ml}$ PGN. In some experiments, 8 wk HuMC were cultured with cytokines (IL-1 $\beta$, IL-6, IL-8, or IL-12) alone or in combination (Peprotech, Rocky Hill, NJ), in addition to blocking antibodies for IL-1 $\beta$ (R\&D, Minneapolis, MN) and IL-6 (Peprotech, Rocky Hill, NJ). Cells were harvested and prepared for flow cytometry, mediator and cytokine release, and real-time PCR for analysis of protease expression.

\section{BMMC from WT and TLR4 KO mice}

WT (C57BL/6, C3H/HeOuJ), TLR4 $\mathrm{KO}(\mathrm{C} 3 \mathrm{H} / \mathrm{HeJ})$ and TLR2 KO mice ( $<6$ months old, $20 \mathrm{~g}$ ) were obtained from Jackson Laboratories (Bar Harbor, ME). Mouse bone marrow-derived mast cells (BMMC) were cultured from femoral marrow cells in RPMI 1640 medium supplemented with $10 \%$ FBS, $100 \mathrm{U} / \mathrm{ml}$ penicillin, $100 \mu \mathrm{g} / \mathrm{ml}$ streptomycin, $25 \mathrm{mM}$ HEPES, $1.0 \mathrm{mM}$ sodium pyruvate, non-essential amino acids, $0.0035 \%$ 2-mercaptoethanol (complete $\mathrm{RPMI})$ and $30 \mathrm{ng} / \mathrm{ml}$ recombinant mouse (rm) IL-3 (Peprotech, Rocky Hill, NJ). In all experiments, 4-6 wk old BMMC were harvested, washed in complete RPMI, and incubated with 10-50 ng/ml rmSCF (Peprotech, Rocky Hill, NJ), or 3-30 ng/ml rmIL-3 alone or in combination with $100 \mathrm{ng} / \mathrm{ml}$ LPS, $10 \mu \mathrm{g} / \mathrm{ml}$ PGN or $1 \mu \mathrm{g} / \mathrm{ml}$ LTA.

\section{$\beta$-hexosaminidase ( $\beta$-hex) release}

HuMC were sensitized overnight with $100 \mathrm{ng} / \mathrm{ml}$ of biotinylated human IgE (biotIgE). Cells were then washed to remove excess biotIgE, and crosslinked using streptavidin (SA) (BD PharMingen, San Diego, CA) as previously described [28]. $\beta$-hex was reported as $\%$ release. $\% \beta$-hex release after $72 \mathrm{hr}$ was calculated as net relative to the nonactivated cells in the presence of SCF+LPS and compared with HuMC treated with SCF alone.

\section{Histamine, $L T C_{4}$ and $P G D_{2}$ assay}

Cellular histamine content and $\mathrm{LTC}_{4}$ and $\mathrm{PGD}_{2}$ release were examined in duplicate using 1,000-10,000 HuMC washed in HEPES with $0.04 \%$ BSA. Histamine content was analyzed with a commercial histamine ELISA Kit (Immunotech, Cedex, France) and reported as pg/cell. $\mathrm{LTC}_{4}$ and $\mathrm{PGD}_{2}$ release were analyzed by competitive enzyme immunoassay (EIA) (Cayman Chemicals, Ann Arbor, MI) and reported as $\mathrm{ng} / \mathrm{ml}$.

\section{Flow cytometric analysis}

HuMC surface marker and intracytoplasmic staining was performed using a modified approach for mononuclear cells [29]. Briefly, cells were incubated sequentially with one or more of the following conjugated antibodies: $5 \mu \mathrm{g} /$ $\mathrm{ml}$ biotIgE; $2.5 \mu \mathrm{g} / \mathrm{ml}$ R-phycoerythrin (PE) $(1 \mathrm{mg} / \mathrm{ml}$; Ancell, Bayport, MN) or allophycocyanine (APC)-conjugated CD117 (Becton-Dickinson, San Jose, CA), $2.0 \mu \mathrm{g} /$ ml PE5.5 (Caltag/Invitrogen, Carlsbad, CA) or $2.5 \mu \mathrm{g} / \mathrm{ml}$ APC-conjugated streptavidin (SA) $(0.2 \mathrm{mg} / \mathrm{ml} ; \mathrm{BD}$ PharMingen, San Diego, CA) per final volume of $50 \mu \mathrm{l}$ containing 20,000-50,000 nucleated cells). PE conjugated annexin $\mathrm{V}$ was used to determine apoptosis (Detection Kit I; BD PharMingen, San Diego, Ca). In all experiments, 10,000-20,000 cell events were analyzed. Cell analysis was performed using a FACScan and CellQuest software (Becton Dickinson, San Jose, CA).

\section{Intracytoplasmic staining for tryptase, chymase and carboxypeptidase}

HuMCs were fixed and permeabilized using 4\% paraformaldehyde and $1 \times$ PBS with $0.1 \%$ saponin and stained for tryptase, chymase and carboxypeptidase as described $[7,29]$. For tryptase/chymase or tryptase/carboxypeptidase staining, cells were first stained for tryptase using $3 \mu \mathrm{g} / \mathrm{mL}$ mouse antihuman tryptase (Clone G3, $1.14 \mathrm{mg} / \mathrm{mL}$, Chemicon, Temecula, CA) and $5.0 \mu \mathrm{g} / \mathrm{ml}$ PE-conjugated goat antimouse IgG $(0.5 \mathrm{mg} / \mathrm{ml}$, Southern Biotechnology, Birmingham, AL). Cells were washed and incubated with either $3 \mu \mathrm{g} / \mathrm{mL}$ biotinylated mouse antihuman chymase (Clone B7, $3 \mathrm{mg} / \mathrm{mL}$, Chemicon, Temecula, CA) or $3 \mu \mathrm{g} /$ $\mathrm{ml}$ biotinylated mouse antihuman carboxypeptidase (kind gift of Dr. Andrew Walls, University of Southampton, UK). Cells were washed and incubated with $2.5 \mu \mathrm{g} /$ $\mathrm{ml}$ APC-conjugated SA. Cell analysis was performed using 20,000-50,000 nucleated cells per final volume of $50 \mu \mathrm{l}$. In all experiments, 10,000-20,000 cell events were analyzed using a FACScan and CellQuest software. In all experiments, the numbers of HuMC positive for one or more proteases was calculated by multiplying the total number of cells examined in culture by the percentage of gated, single or dual protease positive cells determined using flow cytometry.

\section{Human cytokine immunoassay}

Quantitative enzyme immunoassays for IL-1 $\beta$, IL-2, IL-4, IL-6, IL-8, IL-10, IL-12 (measured as the heterodimer IL12p70), IFN- $\gamma$, SCF and TNF- $\alpha$ in cell-free culture supernatants were performed using the following commercial cytometric bead array (CBA) kits; Human Chemokine Kit and Human Th1/Th2 Cytokine Kit II (BD Biosciences, San Jose, CA) and analyzed on a FACSArray Bioanalyzer. The 
minimum detection levels for the chemokines and cytokines are IL-1 $\beta, 7.2 \mathrm{pg} / \mathrm{mL}, \mathrm{IL}-2,2.6 \mathrm{pg} / \mathrm{mL}, \mathrm{IL}-4,2.6$ pg/mL, IL-6, 3.0 pg/mL, IL-8, 0.2 pg/mL, IL-10, $2.8 \mathrm{pg} / \mathrm{mL}$, IL-12, $1.9 \mathrm{pg} / \mathrm{mL}$, IFN- $\gamma, 7.1 \mathrm{pg} / \mathrm{mL}$ and TNF, $2.8 \mathrm{pg} / \mathrm{mL}$.

\section{Real-time PCR analysis for HuMC and BMMC protease mRNA expression}

Total RNA was isolated from each preparation using the RNeasy Mini Kit (Qiagen, Valencia, CA). For HuMC, one microgram of total cellular RNA was treated for genomic DNA contamination and reverse transcribed using Invitrogen Reverse Transcription reagents and oligo dT. Gene expression was analyzed using real-time PCR on an ABI7500 SDS system. One hundred ng of cDNA was used in each quantitative PCR assay, and tryptase and chymase primer sets (Qiagen, Valencia, CA) for PCR amplifications were designed using Primer Express software (PerkinElmer, Shelton, CT). All reactions were performed in triplicate for 40 cycles. Samples were normalized using the geometric mean of GAPDH15 and data are reported as the ratio of treated cells/untreated control cells. Different stocks of cDNA were used for all amplifications to determine the relative quantities across multiple runs.

For BMMCs, two micrograms of total cellular RNA was treated for genomic DNA contamination and reverse transcribed using the Qiagen genomic DNA wipeout buffer and reverse transcription reagents. For each quantitative PCR assay, fifty ng of cDNA was mixed with PCR mastermix containing primer sets (Qiagen, Valencia, CA) for mouse mast cell proteases (MMCP)-1, MMCP-2, MMCP4, MMCP-5, MMCP-6, carboxypeptidase A (CPA3) or the housekeeping gene $\beta$-actin. As a control, RNA which had not being reverse transcribed to cDNA was used in some PCR reactions. All reactions were performed in triplicate for 40 cycles, and gene expression analyzed using the RealTime PCR cycler ABI PRISM 7700 (Applied Biosystems, Foster City, CA). The relative fold expression levels of MMCPs between treatment groups was calculated as follows; for each sample the threshold cycle $(\mathrm{Ct})$ was determined and normalized to $\beta$-actin $(\Delta \mathrm{Ct})$. The $\Delta \mathrm{Ct}$ of treated cells was then subtracted from untreated control cells $(\Delta \Delta \mathrm{Ct})$ and the relative fold expression was calculated using the formula $2^{\Delta \Delta \mathrm{Ct}}$. cDNA stocks were taken from 3 different cultures of BMMC to determine relative quantities across multiple runs.

\section{Statistical Analysis}

Statistical analysis of data was performed using Student's paired t-Test. Significant differences of the means were represented as either $*(\mathrm{p}<0.05),{ }^{* *}(\mathrm{p}<0.01)$ or $* * *(\mathrm{p}$ $<0.001)$.

\section{Authors' contributions}

ASK performed HuMC growth, LPS and PGN culture and flow cytometric studies; ES performed $\mathrm{PGD}_{2}$ and $\mathrm{LTC}_{4}$ analysis and BMMC WT and KO studies; MK performed cytokine analysis and protease QPCR studies; YW performed mediator release studies, and DDM critically reviewed the data and helped format the paper. All authors read and approved the final manuscript.

\section{Acknowledgements}

The authors wish to thank Dr. Andrew Walls, University of Southampton, UK, for his biotinylated mouse antihuman carboxypeptidase.

This work was supported by the NIAID Division of Intramural Research. MK also performed work under NIH grants ROIHL068546 and ROIHL078860 and the Ernest S. Bazely Trust.

\section{References}

I. Kirshenbaum AS, Goff JP, Semere T, Foster B, Scott LM, Metcalfe DD: Demonstration that human mast cells arise from a progenitor cell population that is $\mathrm{CD}^{3} 4^{+}$, c-kit ${ }^{+}$, and expresses aminopeptidase N (CD I3). Blood 1999, 94:2333-42.

2. Kawakami T, Galli SJ: Regulation of mast-cell and basophil function and survival by IgE. Nat Rev Immunol 2002, 2:773-86.

3. Kulka M, Alexopoulou L, Flavell RA, Metcalfe DD: Activation of mast cells by double-stranded RNA: evidence for activation through Toll-like receptor 3. J Allergy Clin Immunol 2004, I | 4: 174-8.

4. Varadaradjalou S, Feger F, Thieblemont N, Hamouda NB, Pleau JM, Dy $M$, Arock M: Toll-like receptor 2 (TLR2) and TLR4 differentially activate human mast cells. Eur J Immunol 2003, 33:899-906

5. Okumura S, Kashiwakura J, Tomita H, Matsumoto K, Nakajima T, Saito $\mathrm{H}$, Okayama $\mathrm{Y}$ : Identification of specific gene expression profiles in human mast cells mediated by Toll-like receptor 4 and FceRI. Blood 2003, I 02:2547-54.

6. McCurdy JD, Olynych TJ, Maher LH, Marshall JS: Cutting edge: distinct Toll-like receptor 2 activators selectively induce different classes of mediator production from human mast cells. Immunol 2003, I 70: I625-9.

7. Kirshenbaum AS, Akin C, Goff JP, Metcalfe DD: Thrombopoietin alone or in the presence of stem cell factor supports the growth of KIT(CD I I 7)low/MPL(CD I I0)+ human mast cells from hematopoietic progenitor cells. Exp Hematol 2005, 33:4|3-2I.

8. Hoshino K, Takeuchi O, Kawai T, Sanjo H, Ogawa T, Takeda Y, Takeda K, Akira S: Cutting edge: Toll-like receptor 4 (TLR4)deficient mice are hyporesponsive to lipopolysaccharide: evidence for TLR4 as the Lps gene product. J Immunol 1999 , 162:3749-52.

9. Nigo YI, Yamashita M, Hirahara K, Shinnakasu R, Inami M, Kimura M, Hasegawa A, Kohno Y, Nakayama T: Regulation of allergic airway inflammation through Toll-like receptor 4-mediated modification of mast cell function. Proc Natl Acad Sci USA 2006, 103:2286-91.

10. Schnare M, Barton GM, Holt AC, Takeda K, Akira S, Medzhitov R: Toll-like receptors control activation of adaptive immune responses. Nat Immunol 200I, 2:947-50.

II. Yoshioka M, Fukuishi N, Iriguchi S, Ohsaki K, Yamanobe H, Inukai A, Kurihara D, Imajo N, Yasui Y, Matsui N, Tsujita T, Ishii A, Seya T, Takahama M, Akagi M: Lipoteichoic acid downregulates FcepsilonRI expression on human mast cells through Toll-like receptor 2. J Allergy Clin Immunol 2007, I 20:452-6I.

12. Babina M, Rex C, Guhl S, Thienemann F, Artuc M, Beate MH, Zuberbier $\mathrm{T}$ : Baseline and stimulated turnover of cell surface c-Kit expression in different types of human mast cells. Exp Dermatology 2006, I 5:530-37.

13. Qiao H, Andrade MV, Lisboa FA, Morgan K, Beaven MA: Fc\&RI and toll-like receptors mediate synergistic signals to markedly augment production of inflammatory cytokines in murine mast cells. Blood 2006, 107:610-18.

14. McCurdy JD, Lin TJ, Marshall JS: Toll-like receptor 4-mediated activation of murine mast cells. J Leukoc Biol 200I, 70:977-84. 
15. Pasare $C$, Medzhitov R: Toll pathway-dependent blockade of $\mathrm{CD}^{+} \mathrm{CD} 25^{+} \mathrm{T}$ cell-mediated suppression by dendritic cells. Science 2003, 299: 1033-36.

16. Oskeritzian CA, Zhao W, Min H-K, Xia H-Z, Pozez A, Kiev J, Schwartz LB: Surface CD88 functionally distinguishes the MCTC from the MCT type of human lung mast cell. J Allergy Clin Immunol 2005, I I 5: I I 62-68.

17. Shimizu Y, Sakai K, Miura T, Narita T, Tsukagoshi H, Satoh Y, Ishikawa S, Morishita Y, Takai S, Miyazaki M, Mori M, Saito H, Xia H, Schwartz LB: Characterization of 'adult-type' mast cells derived from human bone marrow CD34+ cells cultured in the presence of stem cell factor and interleukin-6. Interleukin-4 is not required for constitutive expression of CD54, Fc\&RI $\alpha$ and chymase, and $C D I 3$ expression is reduced during differentiation. Clin Exp Allergy 2002, 32:872-80.

18. Hurst SM, Wilkinson TS, McLoughlin RM, Jones S, Horiuchi S, Yamamoto N, Rose-John S, Fuller GM, Topley N, Jones SA: Control of leukocyte infiltration during inflammation: IL-6 and its soluble receptor orchestrate a temporal switch in the pattern of leukocyte recruitment. Immunity 200I, 14:705-I4.

19. Barton $\mathrm{BE}$, Jackson JV: Protective role of interleukin-6 in the lipopolysaccharide- galactosamine septic shock model. Infect Immun 1993, 61:|496-99.

20. Onogawa $\mathrm{T}$ : Local delivery of soluble interleukin-6 receptors to improve the outcome of $\alpha$-toxin producing Staphylococcus aureus infection in mice. Immunobiology 2005, 209:65I-60.

21. Gurish MF, Ghildyal N, McNeil HP, Austen KF, Gillis S, Stevens RL: Differential expression of secretory granule proteases in mouse mast cells exposed to interleukin 3 and c-kit ligand. Exp Med 1992, 175:1003-12.

22. Ghildyal N, McNeil HP, Stechschulte S, Austen KF, Silberstein D, Gurish MF, Somerville LL, Stevens RL: IL- 10 induces transcription of the gene for mouse mast cell protease-I, a serine protease preferentially expressed in mucosal mast cells of Trichinella spiralis-infected mice. J Immunol 1992, 149:2123-29.

23. Tchougounova E, Pejler G, Abrink M: The chymase, mouse mast cell protease 4 , constitutes the major chymotrypsin-like activity in peritoneum and ear tissue. A role for mouse mast cell protease 4 in thrombin regulation and fibronectin turnover. J Exp Med 2003, 198:423-31.

24. Maurer M, Wedemeyer J, Metz M, Piliponsky AM, Weller K, Chatterjea D, Clouthier DE, Yanagisawa MM, Tsai M, Galli SJ: Mast cells promote homeostasis by limiting endothelin-I-induced toxicity. Nature 2004, 432:5 I2-16.

25. Metz M, Piliponsky AM, Chen C-C, Lammel V, Abrink M, Pejler G Tsai M, Galli SJ: Mast cells can enhance resistance to snake and honeybee venoms. Science 2006, 313:526-30.

26. Wong GW, Foster PS, Yasuda S, Qi JC, Mahalingam S, Mellor EA, Katsoulotos G, Li L, Boyce JA, Krilis SA, Stevens RL: Biochemical and functional characterization of human transmembrane tryptase (TMT)/tryptase $\gamma$. TMT is an exocytosed mast cell protease that induces airway hyperresponsiveness in vivo via an interleukin-13/interleukin-4 receptor $\alpha /$ signal transducer and activator of transcription (STAT) 6-dependent pathway. J Biol Chem 2002, 277:41906-I5.

27. Takahashi K, Takata M, Suwaki T, Kawata N, Tanimoto Y, Soda R, Kimura I: New flow cytometric method for surface phenotyping basophils from peripheral blood. J Immunol Methods 1993 162:17-21.

28. Jensen BM, Beaven MA, Iwaki S, Metcalfe DD, Gilfillan AM: Concurrent inhibition of Kit- and Fc\&RI-mediated signaling: coordinated suppression of mast cell activation. I Pharmacol Exp Ther 2008, 324: $128-38$.

29. Prussin C, Metcalfe DD: Detection of intracytoplasmic cytokine using flow cytometry and directly conjugated anti-cytokine antibodies. J Immunol Methods 1995, 188:117-28.

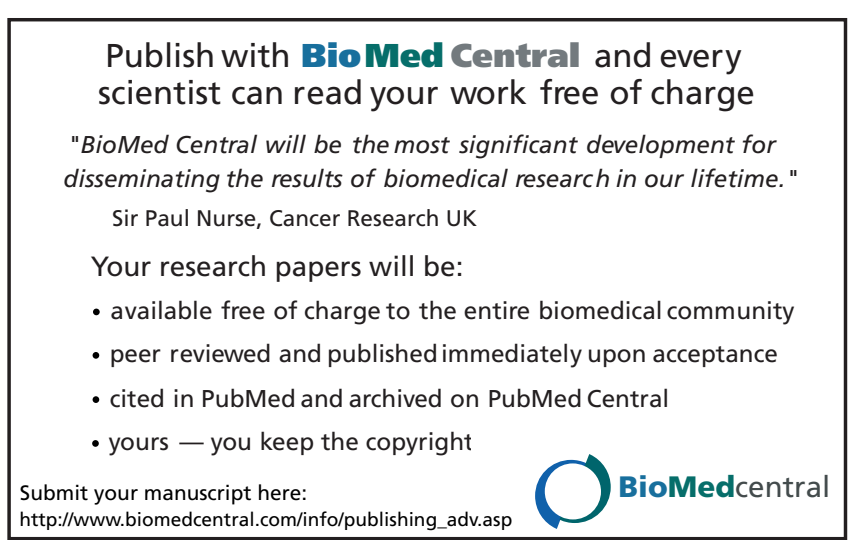

